\title{
Seasonal variation in the Dutch bovine raw milk composition
}

\author{
J. M. L. Heck, ${ }^{* 1}$ H. J. F. van Valenberg, ${ }^{*}$ J. Dijkstra,† and A. C. M. van Hooijdonk* \\ *Dairy Science and Technology Group, Wageningen University, PO Box 8129, 6700 EV Wageningen, the Netherlands \\ †Animal Nutrition Group, Wageningen University, PO Box 338, 6700 AH Wageningen, the Netherlands
}

\section{ABSTRACT}

In this study, we determined the detailed composition of and seasonal variation in Dutch dairy milk. Raw milk samples representative of the complete Dutch milk supply were collected weekly from February 2005 until February 2006. Large seasonal variation exists in the concentrations of the main components and milk fatty acid composition. Milk lactose concentration was rather constant throughout the season. Milk true protein content was somewhat more responsive to season, with the lowest content in June $(3.21 \mathrm{~g} / 100 \mathrm{~g})$ and the highest content in December (3.38 g/100 g). Milk fat concentration increased from a minimum of $4.10 \mathrm{~g} / 100$ $\mathrm{g}$ in June to a maximum of $4.57 \mathrm{~g} / 100 \mathrm{~g}$ in January. The largest (up to 2-fold) seasonal changes in the fatty acid composition were found for trans fatty acids, including conjugated linoleic acid. Milk protein composition was rather constant throughout the season. Milk unsaturation indices, which were used as an indication of desaturase activity, were lowest in spring and highest in autumn. Compared with a previous investigation of Dutch dairy milk in 1992, the fatty acid composition of Dutch raw milk has changed considerably, in particular with a higher content of saturated fatty acids in 2005 milk.

Key words: seasonal variation, milk composition, fatty acid, protein

\section{INTRODUCTION}

Milk and dairy products are important components of western diets. The composition of raw milk determines, to a large extent, the nutritional value and the technological properties of milk and dairy products. Therefore, the composition of milk is of great importance for the dairy industry and there is great interest in changing the composition of milk. The composition of milk varies with stage of lactation, feeding, health status of the cow. and genetic factors (Fox and McSweeney

Received February 19, 2009.

Accepted June 18, 2009

${ }^{1}$ Corresponding author: jeroen.heck@frieslandcampina.com
1998). Because different countries use different breeds and feeding regimens and have different calving patterns and breeding practices, milk composition will also differ among countries. To gain insight into the milk composition in the Netherlands, it is therefore essential to examine the composition of the milk produced by Dutch cows.

The Dutch raw milk composition has changed during the past decades because of changes in the feeding regimen and breeding practices or other changes in dairy husbandry. For example, fat percentage increased from $3.8 \%$ in 1960 to $4.4 \%$ in 2005 (Eurostat, 2008). It is unclear, however, whether the composition of milk fat also changed during this period. A detailed overview of the milk composition is also needed to set a standard to detect favorable or unfavorable changes in the future. An investigation of Swedish dairy milk composition in the 1970s and in 1996 showed a substantial decrease in the CN content of Swedish raw milk during this period (Lindmark-Månsson et al., 2003). Such a decrease in CN content would also be unfavorable for the Dutch dairy industry, because in the Netherlands approximately $50 \%$ of the milk is used for cheese production.

When determining the composition of raw milk, it is important to realize that within one country the composition is not constant. Milk composition varies considerably throughout the seasons, as shown in multiple studies (Jahreis et al., 1996; Auldist et al., 1998; Lindmark-Månsson et al., 2003; Lock and Garnsworthy, 2003). These seasonal changes offer problems and opportunities for dairy manufacturers. Spreadability of butter, for example, is better when it is produced from summer fat compared with winter fat. Studies concerning seasonal variation have tended to be small scale and have studied milk samples from a limited number of cows from one herd (Jahreis et al., 1996; Auldist et al., 1998; Lock and Garnsworthy, 2003). However, milk composition between herds differs markedly, even within herds from the same breed (Stoop et al., 2008). Therefore, these studies may not give a reliable overview of the seasonal variation of the milk supplied to the dairy factories. To our knowledge, only a very limited number of studies have analyzed the raw milk composition that represents the total milk supply of a whole country 
HECK ET AL.

Table 1. Analysis methods used to determine raw milk composition

\begin{tabular}{lll}
\hline Component & Method & Reference \\
\hline Protein, NPN & ISO 8968-1 & ISO (2001) \\
True protein & Calculated; protein, NPN & \\
CN & ISO $17997-1$ & ISO (2004a) \\
CN number & Calculated; CN/true protein & \\
Fat & ISO 1211 & ISO (1999) \\
Lactose & ISO 22662 & ISO (2005) \\
DM & NEN 6844 & NEN (1991) \\
Cell count & ISO $13366-1$ & ISO (1977) \\
Urea & ISO 14637 & ISO (2004b) \\
Freezing point & ISO 5764 & ISO (2002) \\
Protein composition & Capillary zone electrophoresis & Heck et al. (2008) \\
Fatty acid composition & Gas chromatography & Schennink et al. (2007) \\
\hline
\end{tabular}

(Lindmark-Månsson et al., 2003). Furthermore, most studies concerning seasonal variation have analyzed samples only once a month or once a season (Muuse et al., 1986; Palmquist et al., 1993; Wolff et al., 1995; Jahreis et al., 1996). Kelly et al. (1998) and Elgersma et al. (2004) showed that milk composition changes when cows switch from a silage-based diet to a fresh grassbased diet and back. Because such changes in the diet of cows occur very rapidly (e.g., with changing weather conditions), milk composition can change markedly, even on a week-to-week basis. Therefore, to gain better insight into the factors that cause seasonal changes in milk composition in the Netherlands, a higher sampling interval is preferred.

The aim of this study was to provide an up-to-date standard for Dutch raw bovine milk composition and to investigate seasonal variation in the main components and in the composition of the protein and fat fractions. To achieve this, every week for $1 \mathrm{yr}$, we analyzed in detail the milk composition of 1 milk sample that was representative of the total Dutch milk supply.

\section{MATERIALS AND METHODS}

\section{Samples and Methods of Analysis}

The samples used were the same dairy milk samples that are collected routinely by the Dutch milk control station (MCS) as a representative Dutch milk sample. Every week from February 2005 until February 2006, bulk milk samples from 17 dairy plants situated in the Netherlands were collected, pooled, and conserved with $0.03 \%$ sodium azide. In total, 52 milk samples that were representative of the Dutch dairy milk composition in every week in $1 \mathrm{yr}$ were analyzed. All 52 samples were analyzed for all the components using analytical methods, as summarized in Table 1.

Total saturated fat was calculated as the sum of $\mathrm{C} 4: 0$, C5:0, C6:0, C7:0, C8:0, C9:0, C10:0, C11:0, C12:0, C13:0, C14:0 iso, C14:0, C15:0, C15:0 iso, C15:0 an- teiso, C16:0, C16:0 iso, C17:0, C17:0 iso, C17:0 anteiso, C18:0, C19:0, and C20:0. Fatty acid unsaturation indices, namely, the $\mathrm{C} 10$ index, C12 index, C14 index, C16 index, C18 index, and conjugated linoleic acid (CLA) index, as proxies for $\Delta^{9}$-desaturase activity in the mammary gland, were calculated from the ratio between the product and the sum of the product and precursor fatty acid as described by Schennink et al. (2008).

\section{Statistical Analysis}

The mean value for a component was calculated as the weighted mean of all 52 samples. For components that showed seasonal variation, the coefficient of variation $(\mathbf{C V})$, and the minimum and maximum values were calculated. The minimum and maximum values were the monthly averages based on the 4 or 5 samples that represented these months. To determine the presence of seasonal variation in a milk component, the month of sampling was tested as a fixed effect in a general linear model using Genstat, 10th edition (VSN International Ltd., Hemel Hempstead, UK).

\section{RESULTS AND DISCUSSION}

\section{Main Components}

Holstein-Friesian is the predominant dairy breed in the Netherlands (NRS, 2008); therefore, the analyzed milk samples largely reflect the milk composition of Holstein-Friesian cows. Table 2 shows the mean values of several basic milk parameters of Dutch raw milk in 2005. In 2005, fat and protein percentages were higher in raw milk from the Netherlands than in milk from all other European countries in the same year (Eurostat, 2008). When comparing milk composition with the literature values of other countries, it is important to take into account the year in which the samples were taken. Large changes in milk composition in the past decades have occurred in many countries (Eurostat, 2008) be- 
Table 2. Mean, CV, and seasonal variation of several basic milk parameters of Dutch bovine raw milk in 2005

\begin{tabular}{|c|c|c|c|c|c|c|c|}
\hline$\frac{\text { Component }}{\text { Protein }(\mathrm{g} / 100 \mathrm{~g})}$ & $\begin{array}{r}\text { Mean } \\
3.48\end{array}$ & $\frac{\mathrm{CV}}{1.7}$ & \multicolumn{2}{|c|}{ Minimum } & \multicolumn{2}{|c|}{ Maximum } & $\frac{P \text {-value }}{<0.001}$ \\
\hline True protein $(\mathrm{g} / 100 \mathrm{~g})$ & 3.30 & 1.9 & 3.21 & July & 3.38 & December & $<0.001$ \\
\hline $\mathrm{CN}(\mathrm{g} / 100 \mathrm{~g})$ & 2.72 & 1.9 & 2.64 & July & 2.78 & December & $<0.001$ \\
\hline Lactose $(\mathrm{g} / 100 \mathrm{~g})$ & 4.51 & 0.6 & 4.46 & October & 4.55 & May & $<0.001$ \\
\hline $\mathrm{DM}(\mathrm{g} / 100 \mathrm{~g})$ & 13.3 & 1.6 & 12.9 & July & 13.5 & December & $<0.001$ \\
\hline Cell count $\left(10^{3}\right.$ cells $\left./ \mathrm{mL}\right)$ & 186 & 11.1 & 167 & November & 217 & August & $<0.001$ \\
\hline
\end{tabular}

cause of changes in feeding, breeding, and cattle management (e.g., milking frequency) practices. The most recent study on composition of raw dairy milk, on a more detailed level than fat and protein percentages only, was performed in 1996 in Sweden (LindmarkMånsson et al., 2003). Compared with Swedish milk in 1996, Dutch milk in 2005 contained more fat, protein, $\mathrm{CN}$, and DM and less lactose, NPN, and urea. Furthermore, Dutch milk had a higher freezing point and a lower cell count.

Table 2 shows seasonal variation in all components and parameters. The weekly variation in fat, protein, and lactose percentages is shown in Figure 1. In general, fat, protein, true protein, $\mathrm{CN}$, and DM had a minimum value in the summer and a maximum value in the winter. Cell count, NPN, and urea, which is the main constituent of the NPN fraction, had a minimum value in the winter and a maximum value in the summer.
Lactose had a minimum value in autumn and a maximum value in spring. Although the level of the main components can differ, similar seasonal patterns have been found in other studies (Fox and McSweeney 1998; Lindmark-Månsson et al., 2003). In the Netherlands, calving patterns are nonseasonal (NRS, 2008); therefore, seasonal changes in the main components are most likely of dietary origin. Of the main milk components (lactose, fat, and protein), lactose had the smallest and fat the highest variation, with protein in between. This is in line with the general observation that fat is the most sensitive component of milk to dietary changes and lactose is the least sensitive, again with protein in between (Jenkins and McGuire, 2006; Walstra et al., 2006).

General changes in the average Dutch dairy diet composition in 2005 can help to explain the seasonal variation in protein and fat percentages in the milk.

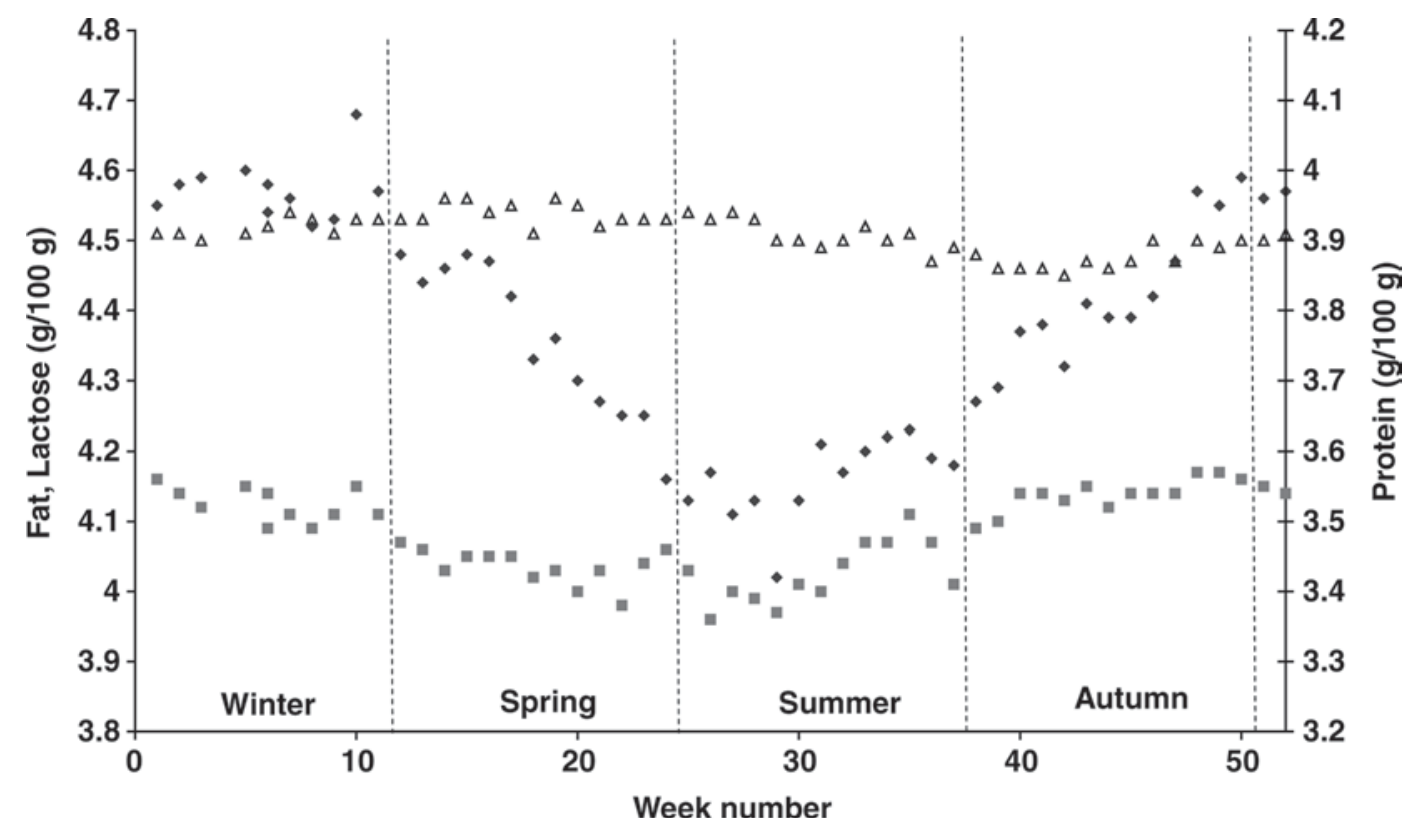
2005.

Figure 1. Weekly variation in the concentration of protein 
Table 3. Mean (g/100 g of true protein), CV, and seasonal variation in the protein composition of Dutch bovine raw milk in 2005

\begin{tabular}{|c|c|c|c|c|c|c|c|}
\hline Component & Mean & $\mathrm{CV}$ & & Minimum & & Maximum & $P$-value \\
\hline CN number ${ }^{1}$ & 82.3 & 0.3 & 81.8 & October & 82.6 & January & 0.023 \\
\hline$\alpha-L A^{2}$ & 2.3 & 5.7 & 2.2 & November & 2.4 & June & $<0.001$ \\
\hline$\beta-\mathrm{LG}^{2}$ & 8.4 & 3.6 & 8.1 & May & 8.8 & February & 0.024 \\
\hline$\alpha_{\mathrm{S}^{2}}-\mathrm{CN}^{2}$ & 10.8 & 3.8 & 10.6 & August & 11.2 & April & NS \\
\hline$\beta-\mathrm{CN}^{2}$ & 27.5 & 2.6 & 26.8 & May & 28.0 & July & NS \\
\hline$\kappa-\mathrm{CN}^{2}$ & 8.2 & 2.3 & 8.1 & March & 8.4 & December & NS \\
\hline
\end{tabular}

${ }^{1} \mathrm{CN}$ number $=(\mathrm{CN} /$ true protein $) \times 100$.

${ }^{2}$ Expressed as grams per $100 \mathrm{~g}$ of true protein.

The major ingredients in Dutch dairy cattle rations include fresh grass, grass silage, corn (Zea mays) silage, and concentrates (Van Bruggen, 2007). During the grazing season (roughly April until September), fresh grass is consumed by most cows (on average $25 \%$ of dietary DM), but the dietary proportion of grass silage is lower than in the winter season (28 and $44 \%$, respectively). In addition, the concentrate proportion is lower in the grazing season $(22 \%)$ than in the winter season $(31 \%)$, whereas the proportion of corn silage (25\%) does not differ. The higher concentrate-to-forage ratio in the winter season is generally associated with lower levels of fiber and higher levels of starch in the diet, which gives rise to an increased production of propionic acid in the rumen (Bannink et al., 2006) and an increased microbial protein supply (Dijkstra et al., 1998). Propionic acid is the major precursor of glucose, followed by AA, and the glucogenic nutrient supply leads to various hormonal signals in the cow that result in an increased milk protein concentration (Jenkins and McGuire, 2006), in line with the observed higher milk protein content in the winter period. A lower milk fat content with fresh pasture (summer) compared with silage (winter) is commonly observed (e.g., Elgersma et al., 2004; Couvreur et al., 2006). The linolenic acid content in fresh grass is much higher than in grass silage, and high levels of linolenic acid are associated with the production of specific long-chain unsaturated fatty acids that inhibit de novo fatty acid synthesis in the mammary gland and reduce the milk fat content (Baumgard et al., 2000).

\section{Protein Composition}

Table 3 shows the mean relative concentrations of the 6 main milk proteins and the $\mathrm{CN}$ number. The 6 main proteins together constitute $90.8 \%$ (wt/wt) of the true protein. The other $9.2 \%$ (wt/wt) consist of minor proteins, including BSA, $\gamma$-CN, proteose peptones, Ig, lactoferrin, lactoperoxidase, and multiple other proteins that occur only in low concentrations. Relative concen- trations of the 6 main milk proteins are in line with literature values (Karman and van Boekel, 1986). Comparing the $\mathrm{CN}$ number with literature values must be done with care because some studies use CN divided by total protein, rather than $\mathrm{CN}$ divided by true protein, to calculate the $\mathrm{CN}$ number. Dividing $\mathrm{CN}$ by total protein would yield a CN number of 78.0 instead of 82.3 . The CN number is in line with other studies reporting on the CN number of milk (Auldist et al., 1998; Coulon et al., 1998; Lindmark-Månsson et al., 2003).

Table 3 shows that protein composition is rather constant throughout the season. This agrees with other studies that have shown that the CN number and protein composition can be influenced by feeding practices only to a small extent (Coulon et al., 1998; Schopen et al., 2009). The only protein that showed highly significant $(P<0.001)$ seasonal variation was $\alpha$-LA. This protein shows a seasonal pattern similar to the amount of lactose in milk. Although the exact mechanism is unknown, this relation between the seasonal pattern of lactose and $\alpha$-LA might be related to the fact that $\alpha-\mathrm{LA}$ is a coenzyme required for lactose production.

\section{Fatty Acid Composition}

Mean Fatty Acid Composition. Table 4 shows the mean fatty acid composition of Dutch bovine milk in 2005. The fatty acids C5:0, C7:0, C9:0, and C11:0 occurred in concentrations below $0.1 \%$ and were not reported in Table 4. The cis double bond of C10:1 and C12:1 could not be ascertained at the carbon-9 position; therefore, these fatty acids were reported as C10:1 and C12:1 in Table 4. The 34 fatty acids listed in the table together constitute approximately $96 \%$ of the total fat. The other $4 \%$ is composed of a very large $(>100)$ number of different fatty acids that were not identified and that occurred in very low concentrations. These unidentified fatty acids constitute almost exclusively unsaturated fatty acids, because the saturated fatty acids known to exist in milk were all identified. Therefore, the total of the saturated fatty acids in Table 4 yielded 
Table 4. Mean (g/100 g of fatty acids), CV, and seasonal variation in the fatty acid composition of Dutch bovine raw milk in 2005

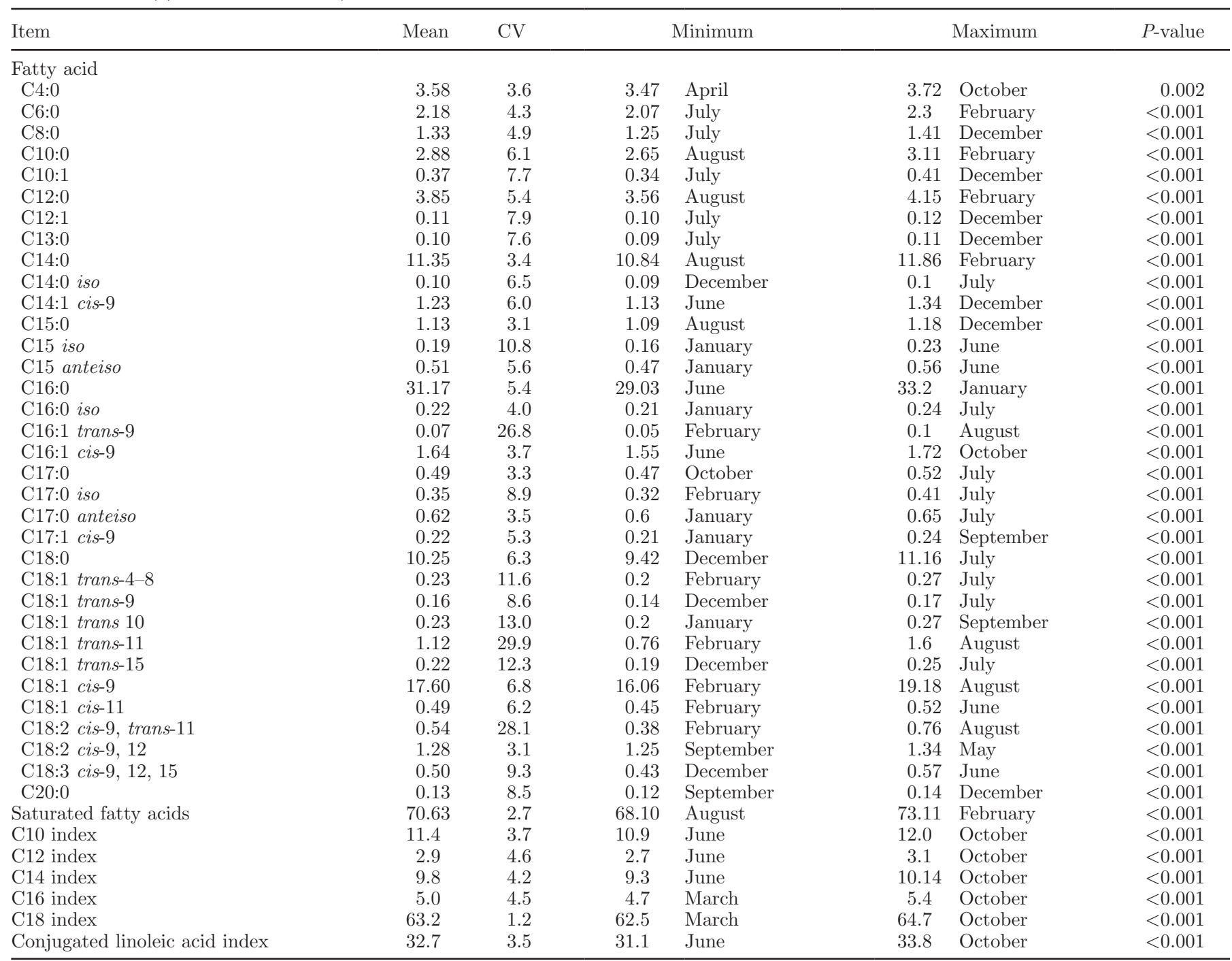

an accurate value for the total proportion of saturated fat in milk fat. On average, $70.6 \%$ of the total fat was saturated. Mean fatty acid composition was in line with values reported by Jensen (2002).

Seasonal Variation in Fatty Acid Composition. Table 4 shows the seasonal variation in all fatty acids. The largest seasonal variation was found in the trans fatty acids. The concentrations of C16:1 trans-9, C18:1 trans-11, and C18:2 cis-9, trans-11 (CLA) were twice as high in summer milk as in winter milk. Based on the seasonal pattern, 2 groups of fatty acids could be distinguished, namely, fatty acids that had a minimum in the summer and a maximum and the winter, and fatty acids that had a minimum in the winter and a maximum in the summer. In general, the fatty acids that had a minimum in the summer were the fatty acids that are synthesized de novo, whereas the fatty acids that had a minimum in the winter were bloodderived fatty acids. Milk C16:0 originates for some 50\% from arterial blood and 50\% from de novo synthesis (Barber et al., 1997), and this fatty acid was also lowest in the summer period. Similar seasonal patterns (i.e., lower proportions of de novo-synthesized fatty acids and higher proportions of the blood-derived fatty acids in the summer) have been reported in French (Wolff et al., 1995), German (Precht and Molkentin, 1999), American (Palmquist et al., 1993), Swiss (Collomb et al., 2008) and Dutch (Muuse et al., 1986) milk. In New Zealand, rather different seasonal patterns in fatty acids have been observed (Auldist et al., 1998). New Zealand dairy farming is mainly based on the use of pasture, and seasonal calving is adopted to maximize pasture utilization. France and Germany use feeding strategies similar to those in the Netherlands through- 


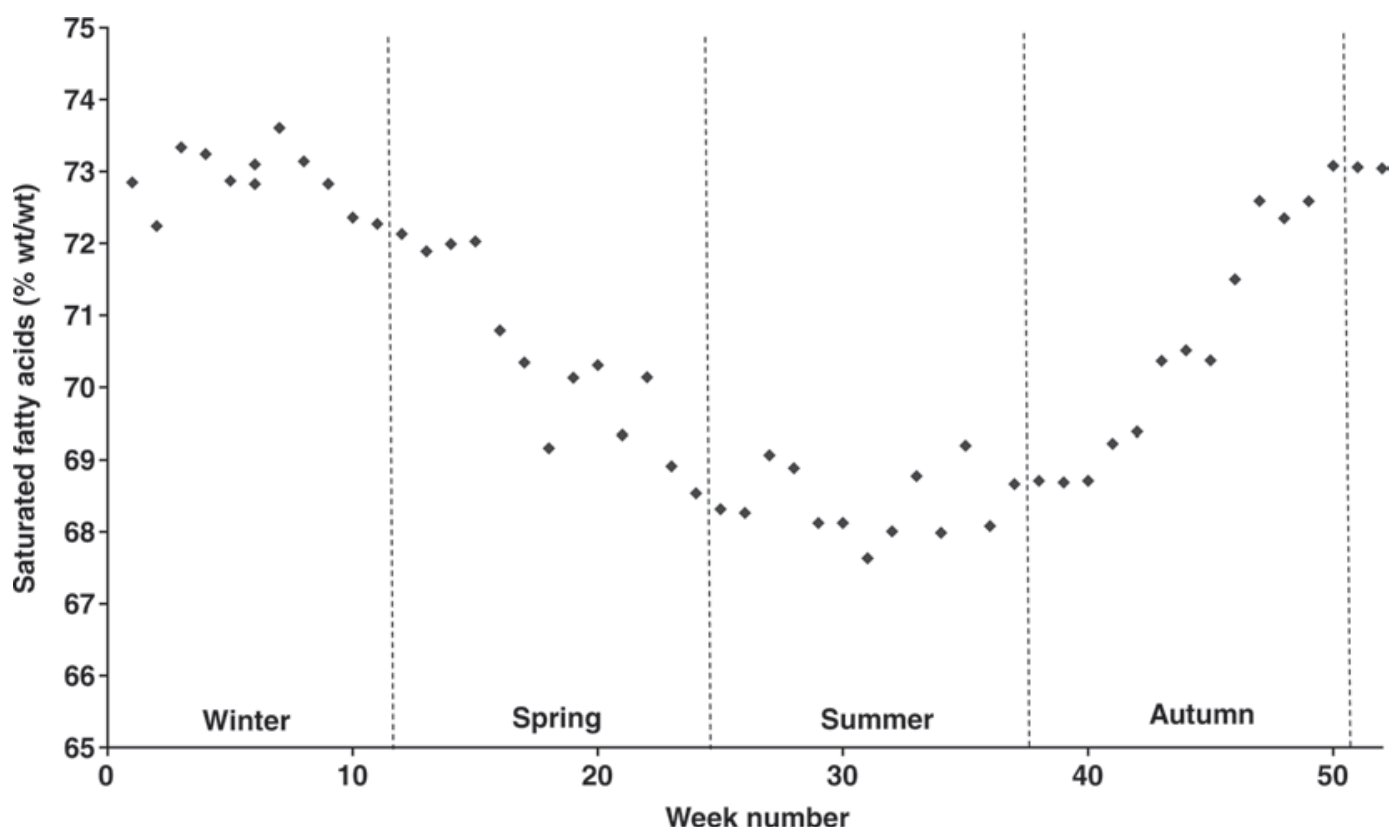

Figure 2. Weekly variation in the concentration of saturated fatty acids (g/100 g of fatty acids) in Dutch bovine raw milk in 2005.

out the season and also do not have a strong seasonal calving pattern.

The weekly changes in the total amount of saturated fatty acids are shown in Figure 2. The amount of saturated fatty acid is highest during the winter period and lowest during the summer. Figure 3 shows the weekly variation of $\mathrm{C} 18: 1$ cis- $9, \mathrm{C} 18: 1$ trans-11, C18:2 cis-9, trans-11 (CLA), and C18:3 cis-9, 12, 15. These fatty acids showed a low proportion throughout the winter and a maximum in the summer. The position of the maximum for C18:3 cis-9, 12, 15 (June) differed from the position of the maximum of the other 3 fatty acids (August).

Possible Causes of Seasonal Variation in Fatty Acid Composition. The seasonal patterns in concentrations of the individual fatty acids were most likely the result of many interdependent factors. However, 3 main factors, that are known to affect the fatty acid composition, might play an essential role: 1) the supply of fatty acids through the diet, 2) rumen microbial metabolism, and 3) the activity of the stearoyl-coenzyme A desaturase (SCD) enzyme.

The diet of the cow has a large impact on the fatty acid composition of the milk (Palmquist et al., 1993). In the Netherlands, an average dairy diet in the summer period has 25\% (DM basis) fresh grass (Van Bruggen, 2007). The winter diet does not contain fresh grass but is composed of more concentrate $(31 \%)$ than the summer diet (22\%) and also more grass silage (44 and $28 \%$, respectively). During the wilting and ensiling of grass, extensive lipolysis and oxidative losses of fatty acids in grass occur (Dewhurst et al., 2006). In addition, the grass used for grazing is generally less mature than the grass cut for silage making, which further decreases the levels of polyunsaturated fatty acids in grass silage compared with fresh grass, especially that of C18:3 (Ferlay et al., 2006). Therefore, increasing the dietary fresh grass content generally increases C18:3 concentration of the diet and consequently increases milk fat concentrations of C18:0, C18:1 cis-9, C18:1 trans-11, CLA, and C18:3 cis-9, 12, 15 and decreases concentrations of de novo-synthesized shorter chain fatty acids (see review by Chilliard et al., 2001). Our findings of milk fatty acid composition in summer compared with winter are in line with these observations. The switch from the winter to the summer diet and back occurs in the Netherlands around April (wk 16) and October (wk 41). The exact week numbers in which this transition occurs will vary depending on weather conditions and the choice of the farmers, but in general, this transition will occur for most herds in the Netherlands within a relatively short period of several weeks. These transitions will cause an abrupt change in the supply of different fatty acids through the diet (Elgersma et al., 2004). Figures 2 and 3 show a marked change in fatty acid composition around these transition periods. However, except for some weeks during the winter, milk fatty acid composition changes continuously throughout the season and also well before and after this transition period. The amount of C18:3 cis-9, 12, 15, for example, 

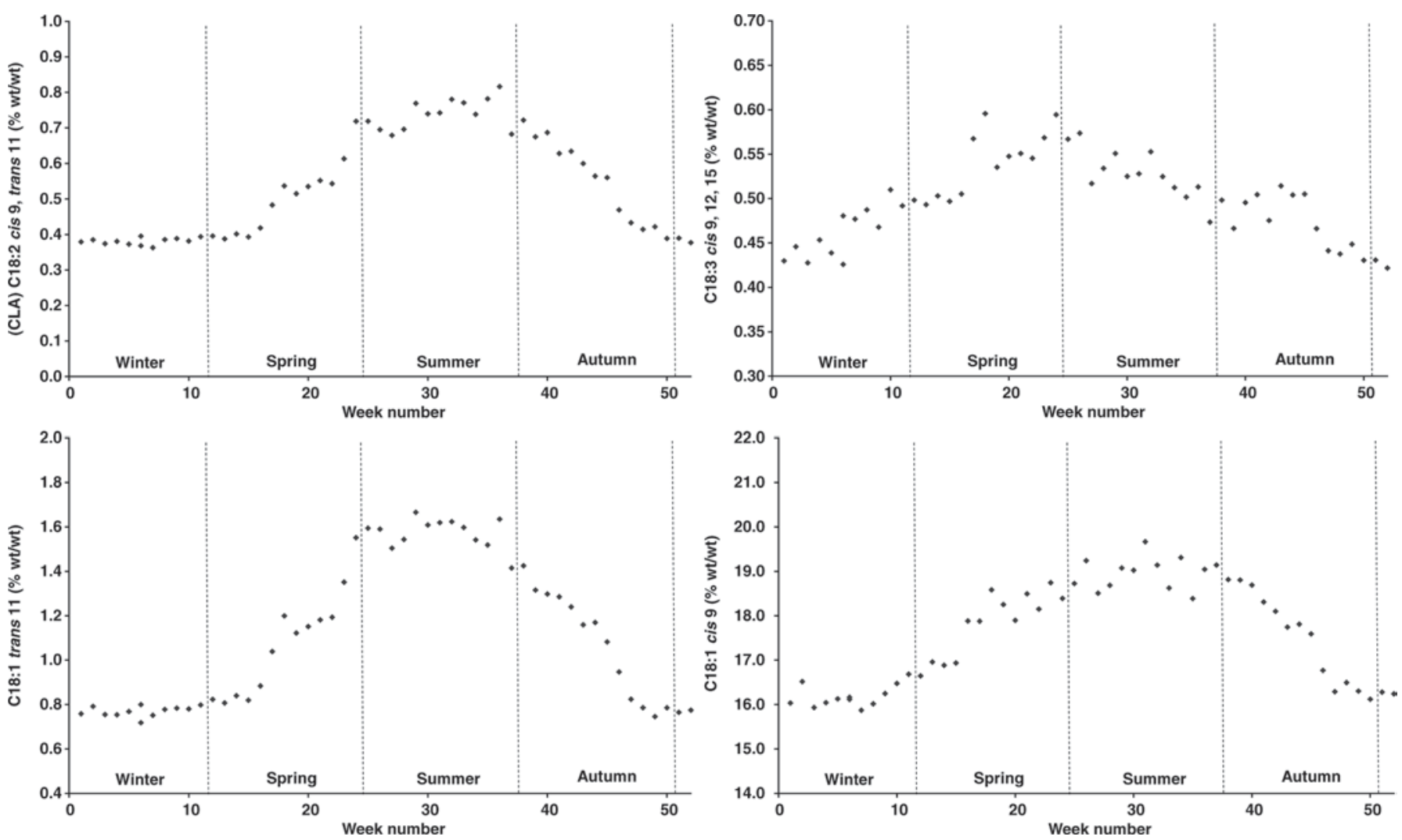

Figure 3. Weekly variation in the concentration of C18:2 cis-9, trans-11 (CLA); C18:3 cis-9, 12, 15; C18:1 trans-11; and C18:1 cis-9 (g/100 g of fatty acids) in Dutch bovine raw milk in 2005.

decreases from the beginning of the stable period and increases again toward the end of the stable period. Furthermore, concentrations of $\mathrm{C} 18: 2$ cis-9, trans-11 (CLA) keep increasing well after the spring transition period to a maximum in late summer. These continuous changes in the fatty acid composition might be caused by the fact that even within the summer and winter diets, the composition of the diet varies. Within the grazing period, grass quality and grass supply varies and the intake of fatty acids during this period may not be constant. The amount of $\mathrm{C} 18: 3$ cis-9, 12, 15 in perennial ryegrass in the Netherlands in 2005 decreased slightly from April to May, in July reached the same level as April, and continued to increase afterward (Witkowska et al., 2008). From late summer onward, grass growth is reduced and the proportion of grass in the total diet decreases or cows have less opportunity to select the fatty acid-rich top layers of the grass, which will counterbalance the increased fatty acid content of the grass. Furthermore, depending on the quality of the grass, the farmer will supplement feeds other than fresh grass. Grass yield and voluntary intake of grass begins to decline toward the end of the summer into autumn, and farmers tend to supplement the diet to a larger extent than in spring and early summer. This might explain the increase in saturated fatty acids beginning from the middle of August.

The unsaturated fatty acids from the feed are extensively biohydrogenated by the rumen microorganisms. During this process, saturated fatty acids and several intermediates, mainly trans fatty acids, are formed. Based on their metabolic pathways, different groups of bacteria can be classified that are involved in different steps of the biohydrogenation process (Lock and Bauman, 2004). Diets that induce a marked reduction in rumen $\mathrm{pH}$, such as high-concentrate diets, cause a shift in bacterial populations, with increased growth of Megasphera elsdenii and reduced growth of Butyrivibrio fibrisolvens (Klieve et al., 2003). Such a shift is related to incomplete biohydrogenation of polyunsaturated fatty acids and increased formation of trans-10 fatty acids rather than trans-11 fatty acids, which reduces de novo fatty acid synthesis in the mammary gland. Therefore, in addition to the direct supply of fatty acids to the milk, the diet indirectly influences the fatty acid composition of milk by altering the rumen bacterial populations or their metabolism.

In various animals, including ruminants, $\Delta^{9}$ desaturase (SCD) adds a cis-9 double bond to different fatty acids (Pereira et al., 2003). Multiple studies have 


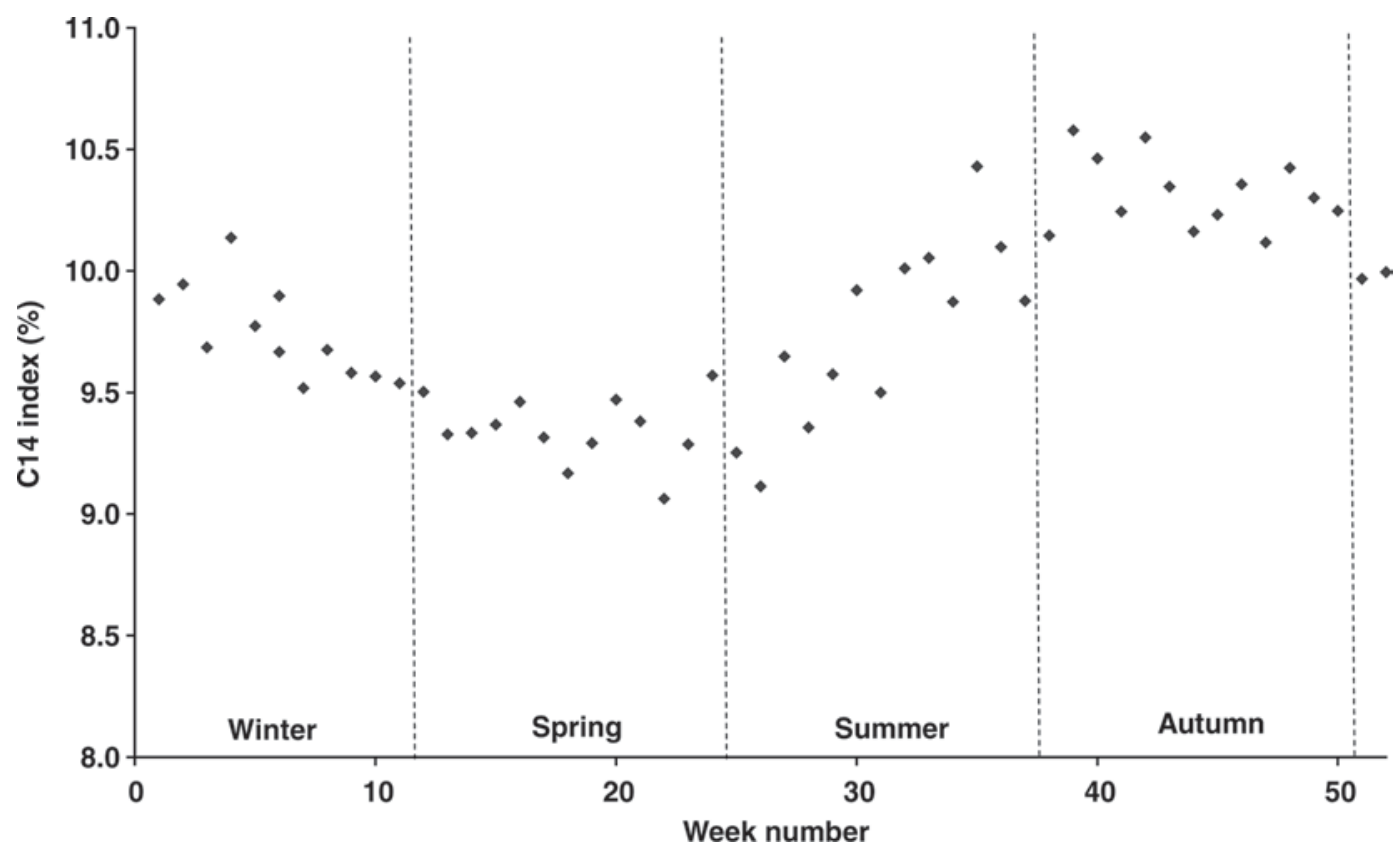

Figure 4. Weekly variation in the C14 index [C14:1 cis-9/(C14:1 cis-9 + C14:0)] calculated from the fatty acid composition of Dutch bovine raw milk in 2005 .

used the ratio of fatty acids in milk that are substrate and product of the SCD enzyme as a measure for the desaturase activity (Kelsey et al., 2003; Lock and Garnsworthy, 2003; Soyeurt et al., 2008). Although this unsaturation index can give an indication of the activity of the enzyme, it is important to realize that the index is not a direct measurement of the enzyme activity and that it is also influenced by other factors (Schennink et al., 2008). Table 4 shows the seasonal variations in the unsaturation indices. A comparison of the $\mathrm{CV}$ values of the indices with the CV values of the substrates suggests that the contribution of the seasonal variation in the desaturase activity to the seasonal variation of the fatty acids that are products of this enzyme varies for the different fatty acids. For some desaturase products, in particular C14:1 cis-9, this contribution was considerable $(\mathrm{CV}$ C14:0 $=3.4$ and CV C14 index $=4.2)$, but for $\mathrm{C} 18: 1$ cis-9 $(\mathrm{CV}$ C18:0 $=6.3$ and $\mathrm{CV}$ C18 index $=$ 1.2) and CLA (CV C18:1 trans-11 $=29.9$ and CV CLA index $=3.5)$, this contribution was very small. This indicates that the seasonal variation, particularly of CLA, is mainly caused by the seasonal variation in the fatty acid supply to the mammary gland (C18:1 trans-11). The weekly pattern of the C14 index (Figure 4) shows that the C14 index was lowest at the end of the spring and highest at the beginning of the autumn. Similar seasonal patterns were found for the other indices (Table 4), although the lowest values for the C16 index and $\mathrm{C} 18$ index were found earlier in spring (March instead of June). These results disagree with the study of Lock and Garnsworthy (2003), who showed that SCD activity was highest in May and June (C14 index) or July (C16 and CLA index), which could partly explain the higher proportion of unsaturated fatty acids in summer milk. However, the present findings for C18:0 are also not in line with those of Lock and Garnsworthy (2003), which were lowest in June in their study but almost highest in ours. In addition, C18:1 cis-9 and $\mathrm{C} 18: 3$ cis-9, 12, 15 did not show a clear seasonal pattern in the report by Lock and Garnsworthy (2003) but had a distinct seasonal pattern in our study.

Comparison of the Fatty Acid Composition Between 1992 and 2005. Figure 5 shows the sum of the even saturated fatty acids C4:0 to C18:0 in Dutch raw milk in 1992 and in 2005. The samples of 1992 were collected in the same manner as in 2005 and were analyzed following the same sample preparation method with the same technique on the same location as in 2005. The figure shows that the seasonal pattern in both years is similar. However, in 1992, the amount of C4:0 to C18:0, and most likely the total amount of saturated fatty acids, was lower compared with 2005 (64.2 and 66.6\%, respectively). This change might be caused by changes in feeding practices or by the breeding strategies used. Figure 5 also shows that in summer the difference in the amount of C4:0 to C18:0 between 2005 and 1992 was greater than in winter. This might be caused by the fact that during the grazing season in 2005, a higher percentage of the cows did not graze outside at all and a smaller percentage of cows had unrestricted 


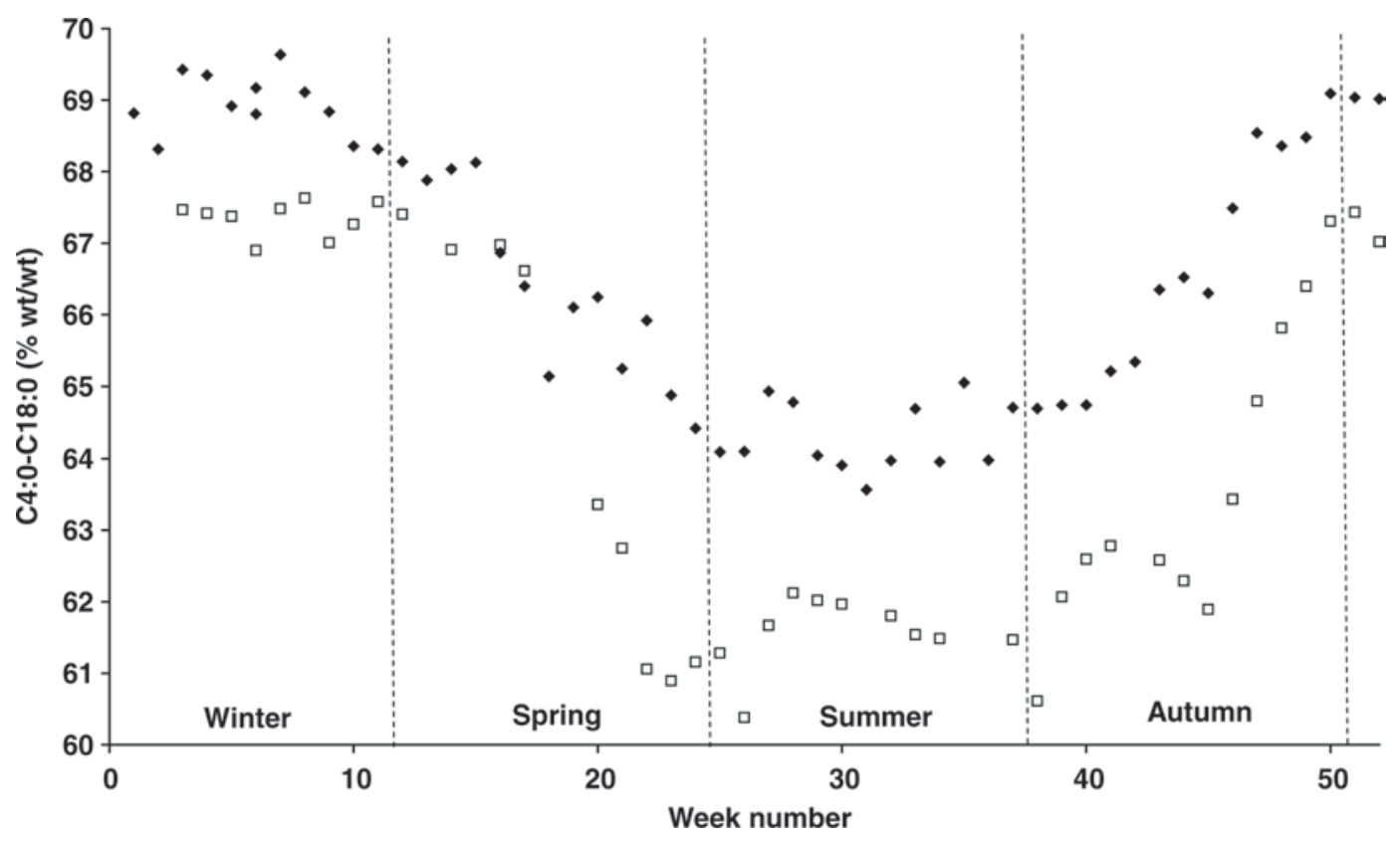

Figure 5. Weekly variation in the concentration of C4:0 to C18:0 (g 100/g of fatty acids) in Dutch bovine raw milk in 2005 ( ) and in 1992 ( $\square$ ). Sum of C4:0, C6:0, C8:0, C10:0, C12:0, C14:0, C16:0, and C18:0.

(day and night) grazing compared with 1992, whereas in the winter period, all cows were confined, both in 2005 and in 1992. Data on fresh grass intake in 1992, obtained in the same way as described by Van Bruggen (2007), also showed a higher dietary grass proportion in 1992 than in 2005 (34 and 12\%, respectively). As discussed previously, a higher proportion of fresh grass in the diet reduces the content of saturated fatty acids in milk. Moreover, the proportion of corn silage in the diet increased from 15 (1992) to $25 \%$ (2005), which may result in an increased saturated fatty acid content in milk compared with grass silage. Finally, nitrogen fertilization levels of grasslands were lower in 2005 than in 1992, resulting in grass and grass silages with a lower $\mathrm{CP}$ content. Because the levels of fatty acids in grass, in particular that of $\mathrm{C} 18: 3$, are positively related to the CP content of grass (Boufaïed et al., 2003), this might further explain the reduced milk contents of saturated fatty acids in 1992 compared with 2005, both in the grazing and nongrazing seasons. The difference between 2005 and 1992 might also be partly the result of the breeding strategies applied. Stoop et al. (2008) showed that selection for a higher fat percentage might result in higher proportions of C16:0. In 1980 to 1984, Dutch butterfat had a mean proportion of $\mathrm{C} 16: 0$ of $27.5 \%$ (Muuse et al., 1986). In 1992, the mean proportion of C16:0 in raw milk was $28.3 \%$ and in 2005 it was $31.2 \%$. The differences in fatty acid composition between 1992 and 2005 clearly show that although milk production and the fat and protein content of the milk of dairy cows in the Netherlands have improved continuously, the quality of the milk fat might have changed in an undesirable manner from a human health perspective. This emphasizes the need to monitor the milk composition in detail, including the concentrations of individual fatty acids, to identify how changes caused by breeding and feeding affect the nutritional value and technological properties of milk.

\section{CONCLUSIONS}

This work provides a standard for the composition of Dutch bovine raw milk in 2005 and provides insight into the seasonal changes in milk composition. Large seasonal variation exists in concentrations of the main milk components and in milk fatty acid composition. The most pronounced changes caused by season occurred for fatty acids, with a clear decrease in proportion of saturated fatty acid and a large increase in trans fatty acids such as CLA during the grazing season. Compared with a similar representative sample of bovine milk in 1992, the level of saturated fatty acids in milk increased markedly. To gain insight into future changes and to speculate whether these changes would negatively influence the nutritional value or technological properties of milk, this research should be repeated in the next decade. 


\section{ACKNOWLEDGMENTS}

This study is part of the Milk Genomics Initiative, funded by Wageningen University, the Dutch Dairy Association (NZO; Zoetermeer, the Netherlands), breeding company Holland Genetics (HG; Arnhem, the Netherlands), and the Dutch Technology Foundation STW (Utrecht, the Netherlands). The authors thank the Milk Control Station [QLIP, formerly MCS; Zutphen, the Netherlands] for the opportunity to use their milk samples.

\section{REFERENCES}

Auldist, M. J., B. J. Walsh, and N. A. Thomson. 1998. Seasonal and lactational influences on bovine milk composition in New Zealand. J. Dairy Res. 65:401-411.

Bannink, A., J. Kogut, J. Dijkstra, J. France, E. Kebreab, A. M. Van Vuuren, and S. Tamminga. 2006. Estimation of the stoichiometry of volatile fatty acid production in the rumen of lactating cows. J. Theor. Biol. 238:36-51.

Barber, M. C., R. A. Clegg, M. T. Travers, and R. G. Vernon. 1997 Lipid metabolism in the lactating mammary gland. Biochim. Biophys. Acta 1347:101-126.

Baumgard, L. H., B. A. Corl, D. A. Dwyer, A. Saebø, and D. E. Bauman. 2000. Identification of the conjugated linoleic acid isomer that inhibits milk fat synthesis. Am. J. Physiol. 278:179-184.

Boufaïed, H., P. Y. Chouinard, G. F. Tremblay, H. V. Petit, R. Michaud, and G. Belanger. 2003. Fatty acids in forages. I. Factors affecting concentrations. Can. J. Anim. Sci. 83:501-511.

Chilliard, Y., A. Ferlay, and M. Doreau. 2001. Effect of different types of forages, animal fat or marine oils in cow's diet on milk fat secretion and composition, especially conjugated linoleicacid (CLA) and polyunsaturated fatty acids. Livest. Prod. Sci. 70:31-48.

Collomb, M., W. Bisig, U. Bütikofer, R. Sieber, M. Bregy, and L. Etter. 2008. Fatty acid composition of mountain milk from Switzerland: Comparison of organic and integrated farming systems. Int. Dairy J. $18: 976-982$.

Coulon, J. B., C. Hurtaud, B. Remond, and R. Verite. 1998. Factors contributing to variation in the proportion of casein in cow's milk true protein: A review of recent INRA experiments. J. Dairy Res. 65:375-387.

Couvreur, S., C. Hurtaud, C. Lopez, L. Delaby, and J. L. Peyraud 2006. The linear relationship between the proportion of fresh grass in the cow diet, milk fatty acid composition, and butter properties. J. Dairy Sci. 89:1956-1969.

Dewhurst, R. J., K. J. Shingfield, M. R. F. Lee, and N. D. Scollan 2006. Increasing the concentrations of beneficial polyunsaturated fatty acids in milk produced by dairy cows in high-forage systems. Anim. Feed Sci. Technol. 131:168-206.

Dijkstra, J., J. France, and D. R. Davies. 1998. Different mathematical approaches to estimating microbial protein supply in ruminants. J. Dairy Sci. 81:3370-3384.

Elgersma, A., G. Ellen, H. van der Horst, H. Boer, P. R. Dekker, and S. Tamminga. 2004. Quick changes in milk fat composition from cows after transition from fresh grass to a silage diet. Anim. Feed Sci. Technol. 117:13-27.

Eurostat. 2008. Eurostat, Statistics on fat contents and protein contents (cow's milk) (annual data). http://ec.europa.eu/eurostat Accessed Aug. 1, 2008.

Ferlay, A., B. Martin, Ph. Pradel, J. B. Coulon, and Y. Chilliard. 2006. Influence of grass-based diets on milk fatty acid composition and milk lipolytic system in Tarentaise and Montbeliarde cow breeds. J. Dairy Sci. 89:4026-4041.

Fox, P. F., and P. L. H. McSweeney. 1998. Dairy Chemistry and Biochemistry. Blackie Academic and Professional, London, UK.
Heck, J. M. L., C. Olieman, A. Schennink, H. J. F. van Valenberg, M. H. P. W. Visker, R. C. R. Meuldijk, and A. C. M. van Hooijdonk. 2008. Estimation of variation in concentration, phosphorylation and genetic polymorphism of milk proteins using capillary zone electrophoresis. Int. Dairy J. 18:548-555.

ISO. 1977. Milk-Enumeration of somatic cells-Part 1: Microscopic method (Reference method). ISO 13366-1. International Organization for Standardization (ISO), Geneva, Switzerland.

ISO. 1999. Milk - Determination of fat content-Gravimetric method (Reference method). ISO 1211. International Organization for Standardization (ISO), Geneva, Switzerland.

ISO. 2001. Milk —Determination of nitrogen content—Part 1: Kjeldahl method. ISO 8968-1 International Organization for Standardization (ISO), Geneva, Switzerland.

ISO. 2002. Milk-Determination of freezing point-Thermistor cryoscope method (Reference method). ISO 5764. International Organization for Standardization (ISO), Geneva, Switzerland.

ISO. 2004a. Milk-Determination of the casein-nitrogen content-Part 1: Indirect method (Reference method). ISO 17997-1. International Organization for Standardization (ISO), Geneva, Switzerland.

ISO. 2004b. Milk-Determination of urea content-Enzymatic method using difference in $\mathrm{pH}$ (Reference method). ISO 14637. International Organization for Standardization (ISO), Geneva, Switzerland.

ISO. 2005. Milk and milk products-Determination of lactose content by high-performance liquid chromatography (Reference method). ISO-DIS-22662. International Organization for Standardization (ISO), Geneva, Switzerland.

Jahreis, G., J. Fritsche, and H. Steinhart. 1996. Monthly variations of milk composition with special regard to fatty acids depending on season and farm management systems-conventional versus ecological. Fett/Lipid 98:356-359.

Jenkins, T. C., and M. A. McGuire. 2006. Major advances in nutrition: Impact on milk composition. J. Dairy Sci. 89:1302-1310.

Jensen, R. G. 2002. The composition of bovine milk lipids: January 1995 to December 2000. J. Dairy Sci. 85:295-350.

Karman, A. H., and M. van Boekel. 1986. Evaluation of the Kjeldahl factor for conversion of the nitrogen content of milk and milk products to protein content. Neth. Milk Dairy J. 40:315-336.

Kelly, M. L., E. S. Kolver, D. E. Bauman, M. E. van Amburgh, and L. D. Muller. 1998. Effect of intake of pasture on concentrations of conjugated linoleic acid in milk of lactating cows. J. Dairy Sci. 81:1630-1636.

Kelsey, J. A., B. A. Corl, R. J. Collier, and D. E. Bauman. 2003. The effect of breed, parity, and stage of lactation on conjugated linoleic acid (CLA) in milk fat from dairy cows. J. Dairy Sci. 86:2588-2597.

Klieve, A. V., D. Hennessy, D. Ouwerkerk, R. J. Forster, R. I. Mackie, and G. T. Attwood. 2003. Establishing populations of Megasphaera elsdenii YE 34 and Butyrivibrio fibrisolvens YE 44 in the rumen of cattle fed high grain diets. J. Appl. Microbiol. 95:621-630.

Lindmark-Månsson, H., R. Fondén, and H. E. Pettersson. 2003. Composition of Swedish dairy milk. Int. Dairy J. 13:409-425.

Lock, A. L., and D. E. Bauman. 2004. Modifying milk fat composition of dairy cows to enhance fatty acids beneficial to human health. Lipids 39:1197-1206.

Lock, A. L., and P. C. Garnsworthy. 2003. Seasonal variation in milk conjugated linoleic acid and delta(9)-desaturase activity in dairy cows. Livest. Prod. Sci. 79:47-59.

Muuse, B. G., G. A. Werdmuller, J. P. Geerts, and R. J. de Knegt. 1986. Fatty acid profile of Dutch butterfat. Neth. Milk Dairy J. 40:189-201.

NEN. 1991. Milk-Determination of dry matter. NEN 6844. Dutch Normalization Institute (NEN), Delft, the Netherlands.

NRS. 2008. Year Statistics 2005. The Royal Dutch Cattle Syndicate (NRS), Arnhem, the Netherlands.

Palmquist, D. L., A. D. Beaulieu, and D. M. Barbano. 1993. Feed and animal factors influencing milk fat composition. J. Dairy Sci. 76:1753-1771.

Pereira, S. L., A. E. Leonard, and P. Mukerji. 2003. Recent advances in the study of fatty acid desaturases from animals and lower 
eukaryotes. Prostaglandins Leukot. Essent. Fatty Acids 68:97106.

Precht, D., and J. Molkentin. 1999. Analysis and seasonal variation of conjugated linoleic acid and further cis-/trans-isomers of C18:1 and C18:2 in bovine milk fat. Kiel. Milchwirtsch. Forschungsber. 51:63-78.

Schennink, A., J. M. L. Heck, H. Bovenhuis, M. H. P. W. Visker, H. J. F. van Valenberg, and J. A. M. van Arendonk. 2008. Milk fatty acid unsaturation: Genetic parameters and effects of stearoyl-CoA desaturase (SCD1) and acyl CoA:diacylglycerol acyltransferase 1 (DGAT1). J. Dairy Sci. 91:2135-2143.

Schennink, A., W. M. Stoop, M. H. P. W. Visker, J. M. L. Heck, H. Bovenhuis, J. J. van der Poel, H. J. F. van Valenberg, and J. A. M. van Arendonk. 2007. DGAT1 underlies large genetic variation in milk-fat composition of dairy cows. Anim. Genet. 38:467-473.

Schopen, G. C. B., J. M. L . Heck, H. Bovenhuis, M. H. P. W. Visker, H. J. F. van Valenberg, and J. A. M. van Arendonk. 2009. Genetic parameters for major milk proteins in Dutch Holstein-Friesians. J. Dairy Sci. 92:1182-1191.

Soyeurt, H., F. Dehareng, P. Mayeres, C. Bertozzi, and N. Gengler. 2008. Variation of $\Delta^{9}$-desaturase activity in dairy cattle. J. Dairy Sci. 91:3211-3224.
Stoop, W. M., J. A. M. van Arendonk, J. M. L. Heck, H. J. F. van Valenberg, and H. Bovenhuis. 2008. Genetic parameters for major milk fatty acids and milk production traits of Dutch HolsteinFriesians. J. Dairy Sci. 91:385-394.

Van Bruggen, C. 2007. Dierlijke mest en mineralen 2005. Centraal Bureau voor de Statistiek, Voorburg/Heerlen, the Netherlands.

Walstra, P., J. T. M. Wouters, and T. J. Geurts. 2006. Dairy Science and Technology. Taylor and Francis, Abingdon, Oxford, UK.

Witkowska, I. M., C. Wever, G. Gort, and A. Elgersma. 2008. Effects of nitrogen rate and regrowth interval on perennial ryegrass fatty acid content during the growing season. Agron. J. 100:13711379 .

Wolff, R. L., C. C. Bayard, and R. J. Fabien. 1995. Evaluation of sequential methods for the determination of butterfat fatty acid composition with emphasis on trans-18:1 acids. Application to the study of seasonal variations in French butters. J. Am. Oil Chem. Soc. $72: 1471-1483$ 